\title{
THE ANALYSIS OF THE IMPACT ON THE SAFETY OF TRAFFIC PARTICIPANTS AND CAUSING THE ACCIDENTS OF WORKING MACHINES - TRACTORS
}

\author{
Žarko Bojić, Milan Radošević, Ilija Ćosić, Slobodan Morača, Nenad Avramović, Aco Antić
}

Subject review

The paper analyses traffic accidents in which one of the participants were tractors, in the period of eleven years $(2002-2012)$ on the territory of the Republic of Serbia. The aim of the research is the exploration of the consequences, number and type of causes of these type accidents, in order to create a knowledge base that is needed for the improvement of the construction and identification of tractors, from the aspect of safety. Data analysis was performed on the sample of $n=13246$ traffic accidents in which one of the participants was a tractor. The authors used one-way analysis of variance (ANOVA) including post hoc test (Scheffe). The significance of the study lies in the precise detection of the connection between the consequence and the number and types of causes in this aspect of accidents, while stressing the need for a more detailed approach in the prevention of accidents.

Keywords: analysis of variance technique; post hoc Scheffe test; tractors; traffic safety

Analiza utjecaja na bezbjednost sudionika u prometu i uzrokovanje nezgoda radnih strojeva - traktora

Pregledni članak

U radu su analizirane prometne nezgode u kojima je jedan od sudionika traktor u razdoblju od jedanaest godina (2002. - 2012.) na teritoriji Srbije. Cilj rada je istraživanje posljedica, broja i vrsta uzroka kod ovog tipa nezgoda, kako bi se stvorile baze znanja neophodne za unapređenje konstrukcije i označavnje traktora s aspekta bezbjednosti. Analiza podataka provedena je na uzorku od $n=13246$ prometnih nezgoda u kojima je jedan sudionik traktor. Autori su koristili jednosmjernu analizu varijance (ANOVA) uključujući i post hoc test (Scheffe). Značaj studije je u preciznijem otkrivanju veza između posljedica, broja i vrste uzroka kod ovog tipa nezgoda uz naglašavanje potrebe za detaljnijim pristupom u prevenciji nezgoda.

Keywords: analiza tehnike varijance; post hoc Scheffe test; sigurnost u prometu; traktori

\section{Introduction}

A work accident is defined as an injury that occurs in a causal relationship with the performance on the job, at work, on the way to the work place, as well as injury that occurs in traffic [1]. A traffic accident is an accident that occurs on the road or it is started on the road, which was attended by at least one vehicle in motion, and in which at least one person was killed or injured, or material damage occurred [2]. The consequences that arise from traffic accidents are reflected in the injuries of traffic participants with mild, severe or fatal consequences, material damage, and they certainly have social and economic impacts [37]. According to the researches of the World Health Organization (WHO), road traffic injuries were the leading cause of death in 2012, with some 330 adolescents dying every day, which means that traffic accidents represent a phenomenon with the highest number of death causes [8]. These data point to the importance of increasing awareness of the road safety on the individual level and on the level of society as a whole.

According to the reports of the Ministry of Labour, Employment and Social Affairs - Directorate for Safety and Health at Work of the Republic of Serbia, in all industries, including communications and transportation, more than 30 accidents with death causes and nearly 1000 accidents with severe physical injuries occur annually [9]. According to the available data of the Republic of Croatia, in 2014 in all sectors there were 17 work injuries with death and 1700 with severe consequences. In the Republic of Slovenia in the same period, in all economic activities occurred 26 work injuries resulting in death [10]. On the other hand, there is no verified data from the neighbouring countries that are not EU members, such as Bosnia and Herzegovina, Montenegro and FRY
Macedonia. If we analyse the data from the EU-28 it can be concluded that most injuries occur in the construction, manufacturing, transportation and storage, and agriculture. Statistical data on the European level show that the number of injuries and deaths in traffic and agriculture account for almost $30 \%$ of all work injuries. [11].

The paper is structured in two parts. The first part of the paper gives an overview of the researches on the road safety and safety at work with an emphasis on the tractor as one of the participants in traffic. The second part analyses the traffic accidents on the territory of the Republic of Serbia in which one of the participants was a tractor, during the period from 2002 to 2012. The aim of the research is the identification of the most frequent causes of the accidents in which tractors participated and the consequences such as the number of dead, heavily and slightly injured people, viewed through the safety at work. The aforementioned analysis of the differences between mentioned factors was performed using the one-way analysis of variance (ANOVA) and the post hoc test (Scheffe).

The importance of the study lies in "discovering" the most frequent causes of accidents in which one of the participants is a tractor in order to provide the background for constructors for the improvement of the safety of tractors while reducing the number of accidents.

\section{Theoretical background}

The issue of the road safety continuously increases on the global level, supported by the fact that every day there are new and better laws, statutes, and regulations on issues of road safety. Agencies such as AAA Foundation for Traffic Safety (founded in 1947), the World Road 
Association-PIARC (established in 1909), the Fédération Internationale de l'Automobile - FIA (founded 1904) and many others definitively contribute to the rapid and more successful development of the legal basis for the adoption of new directives of traffic safety.

The report of the Commission for Global Road Safety presented some successful cases on the issues of road safety in countries such as Norway, Japan, Sweden, Australia, etc. One example of good practice is also the case of Vietnam, where policies on the road safety, in 2008, successfully reduced accidents in traffic with consequences of injuries by $12.2 \%$, while the death causes were reduced by $24.3 \%[13,14,15,16]$. The position of the Republic of Serbia on the world scale in terms of the improvement of the traffic safety is shown in the report of the Traffic Safety Agency of the Republic of Serbia, where the implementation of the law and good practices influenced a decrease of the number of traffic accidents from 42,438 in 2011 to 37,559 in 2012 , i.e. the decrease of $11.5 \%$. The number of accidents with injured persons decreased by $6.6 \%$, from 14,119 in 2011 to 13,333 in 2012, while the number of those who were killed in the same period decreased by 47 persons and the number of injured by 906 people $[17,18]$.

The research question proposed by the authors of this paper was: what is the impact of tractors on the number and consequences of traffic accidents? Literary review recognizes that researchers pay great attention on the road accidents in which one of the participants is a tractor. The authors Swanton et al. explored the tractor-related injuries presenting to a state trauma system by using methods of a retrospective observational study [18]. Some authors investigated the trends in truck related fatalities among adults working on farms for a period of 15 years in Australia using regression analysis [19]. Also, there has been studied the influence of alcohol consumption on drivers of tractors and traffic accidents. The authors Gassendi et al. explored the Zagreb County in the Republic of Croatia. The authors pointed out that more than half of fatal injuries in agriculture were caused by tractor drivers who were under the influence of alcohol [20]. Authors Bende and Kuhn explored the risk of tractors on the roads [21] while Janicak researched the effects of the injuries of the tractor operators older than 65 years, from the standpoint of work safety [22]. Costello with the group of authors investigated the risk of driving a tractor on local roads and accidents which have occurred [23].

\section{Methodology}

Statistical analysis was performed by SPSS softwarepackage. One-way analysis of variance (ANOVA) was used for the exploration of differences between more than two groups on specific dependent variable. This analysis included a post-hoc test (Scheffe) that indicates statistically significant differences between observed groups. Scheffe post hoc test has very strict criteria for determining statistical significance. For the independent categorical variable a group was taken that defines the cause of the accident in which a tractor participated, and for the dependent variable the total number of accidents, number of killed, injured, etc. were taken.

Tractors are high-risk and specific traffic participants. The specificity is primarily reflected in the design of tractors and working machines and their attached trailers and tools (plows, harrows, trailers, special-purpose trailers, etc.), then in the speed of tractors which leads to the slowing of the traffic, etc. According to the structure of the data, in traffic accidents in the Republic of Serbia in the period of 11 years, there were 13246 traffic accidents in which one of the participants was a tractor, and the number of injured persons was 6318. Fig. 1 provides an overview of the casualties by category of participants in the road accidents.

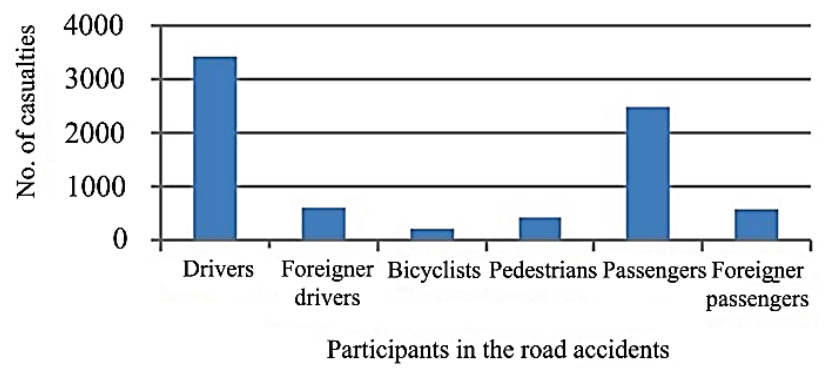

Figure 1 The casualties by category of participants in the road accidents with tractor drivers (source: The authors of the paper)

Table 1 The overview of the locations and the injuries in the traffic accidents for the period from 2002 to 2012 regarding the category of the participants in traffic in Serbia [24]

\begin{tabular}{|c|c|c|c|c|c|c|}
\hline Year & $\begin{array}{l}\text { Category of } \\
\text { participants }\end{array}$ & \multicolumn{3}{|c|}{ Place where the people who took part in the traffic died } & \multicolumn{2}{|c|}{ Seriousness of bodily injury } \\
\hline \multirow{8}{*}{$\begin{array}{l}\text { From } 2002 \text { to } \\
2012\end{array}$} & & On-site & $\begin{array}{c}\text { On the way to health } \\
\text { facilities }\end{array}$ & In a hospital & Slightly & Serious \\
\hline & Drivers & 327 & 65 & 52 & 957 & 2016 \\
\hline & Foreign drivers & 38 & 7 & 3 & 149 & 416 \\
\hline & Cyclists & 10 & 4 & 4 & 77 & 120 \\
\hline & Pedestrians & 15 & 14 & 2 & 135 & 254 \\
\hline & Travelers & 114 & 42 & 39 & 710 & 1566 \\
\hline & Foreign travellers & 35 & 13 & 7 & 139 & 377 \\
\hline & Other participants & 0 & 0 & 0 & 2 & 1 \\
\hline & Total: & 539 & 145 & 107 & 2169 & 4750 \\
\hline
\end{tabular}

In the total number of casualties in traffic accidents, involving the tractor as a vehicle, $44 \%$ of people with fatal causes were drivers, $32 \%$ were passengers, $8 \%$ were drivers from other states (foreign drivers), $7 \%$ were passengers from other countries (foreign travellers), $6 \%$ were pedestrians, $3 \%$ were cyclists, while the percentage of other road users involved was negligible. The overview of the locations (on site of accidents, on the way to health 
facilities, in a medical institution) and the injuries (slightly or serious physical injuries) in the traffic accidents for the period from 2002 to 2012 regarding the category of the participants in traffic in Serbia is presented in Tab. 1.

From the data in Tab. 1 we can conclude that, according to the location of traffic accidents, $68.14 \%$ of injured persons with fatal consequences were on the site of traffic accident, $18.33 \%$ died on the way to the health institutions and $13.52 \%$ died in hospitals. In order to analyse in detail the factors that influenced the number of traffic accidents, or to analyse differences, it is necessary to explore the causes of accidents and their impact on the number of casualties, injury severity, and the level of material damage, which are presented in Tab. 2.

Table 2 The relation between the causes and consequences of traffic accidents with tractors for the period from 2002 to 2012 in Serbia [24]

\begin{tabular}{|c|c|c|c|c|c|c|}
\hline Year & Causes & \multicolumn{3}{|c|}{ Consequences } & \multicolumn{2}{|c|}{ Seriousness of bodily injury } \\
\hline \multirow{14}{*}{$\begin{array}{l}\text { From } \\
2002 \\
\text { to } \\
2012\end{array}$} & & $\begin{array}{l}\text { Number of } \\
\text { casualties }\end{array}$ & $\begin{array}{c}\text { Number of } \\
\text { persons killed }\end{array}$ & $\begin{array}{c}\text { Material } \\
\text { damage }\end{array}$ & Serious & Slightly \\
\hline & Opposite direction crash & 761 & 49 & 1641 & 299 & 854 \\
\hline & Sidewise direction crash & 518 & 32 & 1288 & 158 & 550 \\
\hline & Same direction crash & 1387 & 114 & 2245 & 537 & 1607 \\
\hline & Crash with parallel driving & 23 & 3 & 92 & 5 & 20 \\
\hline & Strike in stopped or parked vehicle & 272 & 18 & 1399 & 89 & 282 \\
\hline & Strike in object on the road & 31 & 4 & 174 & 5 & 25 \\
\hline & Rollover of vehicle on the road & 349 & 146 & 56 & 152 & 205 \\
\hline & Landing of vehicle off the road & 1011 & 255 & 310 & 418 & 555 \\
\hline & $\begin{array}{l}\text { Landing of vehicle off the road and strike } \\
\text { in object on the road }\end{array}$ & 130 & 17 & 311 & 45 & 91 \\
\hline & Mutual crashes of the road and rail vehicles & 34 & 12 & 31 & 13 & 35 \\
\hline & Falling from a moving vehicle & 491 & 83 & 4 & 243 & 201 \\
\hline & Run over pedestrians & 315 & 29 & 4 & 114 & 199 \\
\hline & Other types of accidents & 205 & 29 & 200 & 91 & 126 \\
\hline & Total: & 5527 & 791 & 7755 & 2169 & 4750 \\
\hline
\end{tabular}

\section{Results}

The analysis of the structure of the road accidents in the Republic of Serbia for a period of 11 years in which one of the participants was a tractor shows that there were a total of 6919 injuries, with 2169 severe and 4750 minor injuries. When observing the categories of participants who were killed, drivers and passengers make up $76 \%$ of the total casualties (Fig. 1). If we observe the location of the accidents, 327 drivers and 114 passengers died on the site of the accident, 65 drivers and 42 passengers died on the way to the hospital, while 52 drivers and 39 passengers died in the hospital (Tab. 1). If we analyse the causes that led to accidents and injuries (Tab. 2) we can conclude that the crashes when driving in the same direction caused 1387 victims, landing of vehicle off the road caused 1011 injuries, crash from opposite directions caused 761 injuries, etc. The largest number of fatalities was caused by landing of vehicle off the road, which caused death of 255 persons. The next most important reasons that have induced fatal consequences were rollover of vehicle on the road (146 persons) and the same direction crash (114 persons). The Agency for Traffic Safety classified traffic accidents into 13 groups in their records, which differ in frequency. Due to these characteristics, which can be seen in Tab. 2, it was not possible to perform statistical analysis with thus formed groups. For the purposes of this research four groups were formed to examine which type of accident has the largest share in the total number of injured, injured persons and material damage. Groups are formed on the basis of the shared characteristics of the cause of the accident - crash, strike, landing, and others. The first group consists of accidents that are integrated as crashes; they include crash from opposite directions, sidewise crash, crash when driving in the same direction, crash with the parallel driving, and mutual crashes with road and rail vehicles. The second group of accident causes is called strikes and it is defined by two types of strikes, strike in stopped or parked vehicle and strike in an object on the road. The third group of the cause is landing which represents accidents involving tractors and includes rollover of vehicles on the road, landing vehicles off the road and landing vehicles and strike in an object on the road. The fourth group of causes is others, or falling of persons from moving vehicles, run over pedestrians and other types of accidents. To test the difference between groups there has been used one-way-analysis of variance (ANOVA), aimed at examining the differences between the various groups. This analysis included the post hoc test (Scheffe) that indicates which differences between groups are statistically significant. An independent categorical variable was the group that defines the cause of traffic accident with tractor, while dependent variables were the total number of accidents, number of killed people, number of injured people, number of minor and serious injuries, and material damage.

When the number of traffic accidents is observed as separate dependent variable, it can be seen that the largest number of traffic accidents with tractors occurs exactly as crashes, 725.81 annually. The least of accidents are caused by a group of other causes, 111.63. Other indicators of groups are presented in Tab. 3.

Results of the one-way analysis of variance indicated that there is a statistically significant difference among groups $(F=61.52, p<0.01)$ of the number of accidents regarding the causes of the accidents. Based on the post hoc tests, it can be concluded that crashes significantly cause the greatest number of accidents where tractors participated. The test results are presented in Tab. 4. 
Table 3 The number of traffic accidents regarding the category of causes

\begin{tabular}{|c|l|r|r|r|r|}
\hline \multicolumn{2}{|c|}{} & Means & $\begin{array}{c}\text { Stand. } \\
\text { Dev. }\end{array}$ & \multicolumn{1}{c|}{ Min } & \multicolumn{1}{c|}{ Max } \\
\hline \multirow{3}{*}{\begin{tabular}{c} 
Total $\begin{array}{c}\text { Tol } \\
\text { number of } \\
\text { accidents }\end{array}$ \\
\cline { 2 - 7 }
\end{tabular}} & Crashes & 725.81 & 233.02 & 338.00 & 1001.00 \\
\cline { 2 - 7 } & Strikes & 170.54 & 57.76 & 74.00 & 254.00 \\
\cline { 2 - 7 } & Oanding & 197.00 & 18.50 & 165.00 & 221.00 \\
\cline { 2 - 7 } & Others & 111.63 & 15.06 & 77.00 & 129.00 \\
\hline
\end{tabular}

Table 4 Post hoc test - the number of traffic accidents

\begin{tabular}{|c|c|c|c|}
\hline \multirow{2}{*}{ Causes } & \multirow{2}{*}{$N$} & \multicolumn{2}{|c|}{ Subset for alpha $=0.05$} \\
\cline { 3 - 4 } & & 1 & 2 \\
\hline Others & 11 & 111.63 & \\
\hline Strikes & 11 & 170.54 & \\
\hline Lending & 11 & 197.00 & \\
\hline Crashes & 11 & & 725.81 \\
\hline Sig. & & 0.441 & 1.000 \\
\hline
\end{tabular}

The authors examined the extent to which the cause of the accident influences the casualties. On the average, during the year most of the casualties of traffic accidents were in crashes, while the least were in strikes.

To test differences the one-way analysis of variance was used. It proved to be statistically significant, $F=135.06 ; p<0.001$. Number of accidents with causalities will vary depending on the cause of traffic accidents in which one of the participants was a tractor. Post hoc analysis showed that the number of such accidents is statistically significantly different in all groups.

Tab. 5 shows the number of persons killed regarding the causes of accidents in which one of the participants was a tractor. It can be noticed that the largest number of people were killed in accidents that occurred during landing (36.54), while the lowest number of people were killed in strikes (2.18).

Table 5 The number of people killed in traffic accidents with tractors regarding the category of causes

\begin{tabular}{|c|l|r|r|r|r|}
\hline \multicolumn{2}{|c|}{} & Mean & $\begin{array}{c}\text { Stand. } \\
\text { Dev. }\end{array}$ & \multicolumn{1}{c|}{ Min } & \multicolumn{1}{c|}{ Max } \\
\hline \multirow{2}{*}{$\begin{array}{c}\text { Total } \\
\text { number } \\
\text { of people } \\
\text { killed }\end{array}$} & Crashes & 20.27 & 7.84 & 5.00 & 32.00 \\
\cline { 2 - 6 } & Strikes & 2.18 & 1.60 & 0.00 & 5.00 \\
\cline { 2 - 6 } & Landing & 36.54 & 5.42 & 27.00 & 46.00 \\
\cline { 2 - 6 } & Others & 13.45 & 4.84 & 7.00 & 25.00 \\
\cline { 2 - 6 } & Total & 18.11 & 13.63 & 0.00 & 46.00 \\
\hline
\end{tabular}

Results of one-way analysis of variance showed that the differences between the groups are statistically significant, $F=77.62 ; p<0.001$. Post hoc test shows that in this case there is a difference between each of the groups. Landing of vehicles leads to the greatest number of fatalities, while the smallest number of death causes was in the case of strikes. The number of injured in the accident is shown by the total number of injured, and by the minor and severe injured people. Looking at the descriptive indicators it can be seen that the most of people per year were injured in crashes $(M=370.72$; $S D=67.37)$, followed by landing $(M=133.27, S D=11.84)$, then in other accidents $(M=91.18, S D=15.54)$, and at the end in strikes $(M=36.45, S D=13.37)$.

One-way analysis of variance shows that this difference in numbers is statistically significant, which means that depending on the cause of the accident the number of injured will vary $(F=187.22, p<0.001)$. When the Post Hoc tests are used to compare individual groups, there can be seen three formed categories which differ in the number of injured in the accidents. The data are presented in Tab. 6 . The number of strikes, the number of crashes and the other causes and landings (both in third group) are different with statistical significance.

Table 6 Post hoc test - the number of injured

\begin{tabular}{|c|c|c|c|c|}
\hline \multirow{2}{*}{ Causes } & \multirow{2}{*}{$N$} & \multicolumn{3}{|c|}{ Subset for alpha $=0.05$} \\
\cline { 3 - 5 } & & 1 & 2 & 3 \\
\hline Strikes & 11 & 36.4545 & & \\
\hline Others & 11 & & 91.1818 & \\
\hline Landing & 11 & & 133.2727 & \\
\hline Crashes & 11 & & & 370.7273 \\
\hline Sig. & & 1.000 & 0.069 & 1.000 \\
\hline
\end{tabular}

From the group of injured people there can be isolated the number of seriously injured. Descriptive statistics for the categories related to the number of seriously injured people is shown in Tab. 7. From the table it can be seen that the most seriously injured persons were in crashes, and the least were in strikes.

Table 7 The number of seriously injured people in traffic accidents in which one of the participants was a tractor

\begin{tabular}{|c|l|r|r|r|r|}
\hline \multicolumn{2}{|c|}{} & \multicolumn{1}{|c|}{ Mean } & $\begin{array}{c}\text { Stand. } \\
\text { Dev. }\end{array}$ & \multicolumn{1}{c|}{ Min } & Max \\
\hline \multirow{2}{*}{$\begin{array}{c}\text { Number } \\
\text { of } \\
\text { seriously } \\
\begin{array}{c}\text { injured } \\
\text { people }\end{array}\end{array}$} & Crashes & 92.00 & 22.04 & 61.00 & 121.00 \\
\cline { 2 - 6 } & Strikes & 8.54 & 4.80 & 3.00 & 19.00 \\
\cline { 2 - 7 } & Landings & 55.90 & 7.79 & 42,00 & 66.00 \\
\cline { 2 - 7 } & Others & 42.45 & 9.19 & 31.00 & 62.00 \\
\hline
\end{tabular}

When this group of injured people is examined, it is obvious that there are statistically significant differences between groups, $F=80.09 ; p<0.001$. To explore between which of groups there are statistically significant differences, the authors conducted the post hoc test (Scheffe). The test points out that the groups are distributed as in the table above or similar as in the total number of injured. ANOVA tests indicate that there are statistically significant differences between groups ( $F=223.81, p<0.001)$. Depending on the cause of the accident the number of slightly injured will be changed. Post hoc test indicates that the differences between groups are somewhat different. Number of slightly injured in strikes is significantly less than in other accidents, while in crashes it is significantly higher. The group "others" with the group "landing" is located between other two groups, although the number of slightly injured participants in the group "other" does not differ significantly from those in the group of strikes. The results are shown in Tab. 8.

Table 8 Post hoc test - the number of slightly injured

\begin{tabular}{|c|c|c|c|c|}
\hline \multirow{2}{*}{ Causes } & \multirow{2}{*}{$N$} & \multicolumn{3}{|c|}{ Subset for alpha $=0.05$} \\
\cline { 3 - 5 } & & 1 & 2 & 3 \\
\hline Strikes & 11 & 27.9091 & & \\
\hline Others & 11 & 48.7273 & 48.7273 & \\
\hline Landing & 11 & & 77.3636 & \\
\hline Crashes & 11 & & & 278.7273 \\
\hline Sig. & & 0.318 & 0.093 & 1.000 \\
\hline
\end{tabular}

Traffic accidents lead to a certain degree of material damage. When the material damage in traffic accidents in the period of 11 years appears as the dependent variable, and the causes of accidents as the categorical variable, it 
can be seen that most accidents with material damage occur in crashes $(M=481.54, S D=192.89)$, followed by strikes $\quad(M=143, \quad S D=49.03), \quad$ landings $\quad(M=61.54$, $S D=12.19)$, and in other causes of accidents $(M=16.90$; $S D=7.73$ ).

One-way analysis of variance indicates that among observed categories there were statistically significant differences when the dependent variable is the number of accidents with material damage $(F=48.93 ; p<0.001)$. Post hoc test indicates that accidents with material damage are the most common in crashes, and the least occur in other accidents and in landings. Among these groups there were statistically significant differences. The findings are presented in Tab. 9.

Table 9 Post hoc test - the number of accidents with material damage

\begin{tabular}{|c|c|c|c|c|}
\hline \multirow{2}{*}{ Cause } & \multirow{2}{*}{$N$} & \multicolumn{3}{|c|}{ Subset for alpha $=0.05$} \\
\cline { 3 - 5 } & & 1 & 2 & 3 \\
\hline Others & 11 & 16.9091 & & \\
\hline Landing & 11 & 61.5455 & 61.5455 & \\
\hline Strikes & 11 & & 143.0000 & \\
\hline Crashes & 11 & & & 481.5455 \\
\hline Sig. & & 0.777 & 0.314 & 1.000 \\
\hline
\end{tabular}

\section{Discussion}

The data from the EU-28 show that $66.6 \%$ of work injuries occur in the construction, manufacturing, transportation and storage, and agriculture [11]. In the Republic of Serbia in all industries, including communications and transportation, annually happen more than 30 fatal work injuries and about 1000 with serious body injuries [9]. Since this study analyses traffic accidents in which one of the participants was a tractor, the focus is on the injuries in the field of transport and agriculture. Literary review notes that there are not so many studies that deal specifically with the analysis of traffic accidents in which one of the participants was a tractor (for more see [25-29]). In some studies there have been applied descriptive statistics and ANOVA, while more rigorous statistical tests such as post hoc tests (Scheffe) have not been applied. Although the Scheffe's post hoc test, which has the strictest criteria for determining statistical significance between the groups of data, was applied, the basic flaw in the study is reflected in the lack of available data which are related to road accidents in which one of the participants was a tractor. Those are the weather conditions in which the accident occurred, whether the accident occurred in day or night conditions, the percentage of drivers who were under the influence of alcohol, etc. If these data were available, even more detailed and extensive researches could be conducted to help us in creating more accurate knowledge platform when it comes to these forms of traffic accidents. Data analysis showed that the largest number of accidents, in which one participant was a tractor, was caused by crashes. Crashes also caused the largest number of seriously injured people, while the largest number of persons killed in traffic accidents was in landings. The number of slightly injured in strikes was significantly less than in other incidents, while in strikes it was significantly higher. When considering the material damage in traffic accidents, it can be seen that most accidents with material damage occur in crashes followed by strikes, landings, and in other causes of accidents.
Since one of the goals of the study was "discovering" the most frequent accidents in which one of the participants was a tractor, the need for further research will certainly be based on the obtained data in this study. Future research should be carried out in more direct cooperation with the constructors of the tractors on the market, in order to improve the safety of tractors while reducing the number of accidents.

\section{Conclusion}

Over the past 11 years tractors participated in a number of accidents in the territory of the Republic of Serbia. In the observed time period there were 13246 traffic accidents in which one of the participants was a tractor, and the number of injured persons was 6318 . The presented study indicated the necessity of devoting more attention to the problem of traffic accidents in which one of the participants is a tractor, in synergy with the people who directly or indirectly affect the traffic safety as well as the producers of the tractors.

For the purposes of this study, based on available data, there have been formed four accidents categories: crash, strike, landing and others. The division was made from the standpoint of determining the most critical category for the safety of traffic participants. The results showed those created groups differ in each variable. The results also indicated that crashes as a cause of accidents are dominant when it comes to the number of accidents, number of accidents with casualties, the number of casualties and material damage. Category of landing off the road leads to the greatest number of fatalities and based on the obtained data we concluded that in the future we should pay special attention to the prevention and mitigation of the consequences of the accidents which involve tractors. Also, special attention was focused on crashes when driving in the same direction, which proved to be the most devastating. The results of the study showed that the most frequent accidents on local roads were those in which one of the participants was a tractor. The results provide a background, a knowledge base, for future research in this area. Based on the data of the Ministry, injuries that occur in the field of agriculture related to the traffic, are not significant in number, and they do not represent information which would point that in the field of labour in agriculture there are risks of injuries [9]. Therefore, relevant authorities do not undertake specific action plans in terms of the improvement of conditions in that field. A part of future research or "first small step action" should be implemented in direct conjunction with the constructors of the tractors in order to improve tractors' security while reducing the number of traffic accidents.

\section{References}

[1] Zakon o bezbendosti zdravlja na radu, Sl. Glasnik RS $101 / 2005$

[2] Zakon o bezbednosti saobraćaja na putevima, Sl. Glasnik RS 41/2009, 53/2010, 101/2011, 32/2013 - odluka US i $55 / 2014$

[3] Krafft, M.; Kullgren, A.; Tingvall, C.; Boström, O.; Fredriksson, R. How crash severity in rear impacts influences short-and long-term consequences to the neck. // Accident Analysis \& Prevention. 32, 2(2000), pp. 187-195. https://doi.org/10.1016/S0001-4575(99)00083-4 
[4] Rosen, E.; Sander, U. Pedestrian fatality risk as a function of car impact speed. // Accident Analysis \& Prevention. 41, 3(2009), pp. 536-542. https://doi.org/10.1016/j.aap.2009.02.002

[5] Mooren, L.; Grzebieta, R.; Williamson, A.; Olivier, J.; Friswell, R. Safety management for heavy vehicle transport: A review of the literature. // Safety science. 62, (2014), pp. 79-89. https://doi.org/10.1016/j.ssci.2013.08.001

[6] Cohen, A.; Dehejia, R. The Effect of Automobile Insurance and Accident Liability Laws in Traffic Fatalities. // The journal of law and economics. 47, 2(2004), pp. 357-393. https://doi.org/10.1086/422978

[7] Radović, N.; Mirković, K.; Šešlija, M.; Peško, I. Output and performance based road maintenance contracting - case study Serbia. // Tehnički vjesnik-Technical Gazette. 21, 3(2014), pp. 681-688.

[8] WHO, Adolescents: health risks and solutions, Fact sheet No $345 \quad \mathrm{http}: / / \mathrm{www} . w h o . i n t / m e d i a c e n t r e /$ factsheets/ fs345/en/ (21.12.2014)

[9] Ministarstvo rada zapošljavanja I socijalne politike Republike Srbije, Izveštaj o radu inspektorata za rad za 2012 godinu http://www.minrzs.gov.rs/files/doc/ bezbednost/Izvestaj\%20Inspektorata\%20za\%20rad.pdf (25.12.2014)

[10] Živković, S.; Petrović, D. The comparative analysis of the nubmer of occupational injuries in Serbia, Croatia and Slovenia in 2012.

[11] http://ec.europa.eu/eurostat/statistics-explained/index.php/ Accidents_at_work_statistics (21.12.2014)

[12] Make Roads Safe, A Decade of Action for Road Safety. London, Commission for Global Road Safety, 2011 http://www.makeroadssafehellas.com/images/stories/public ations/decade_of_action_report_lr.pdf (13.01.2015)

[13] Fastenmeier, $\overline{\text { W.; }}$; Gstalter, H. Driving task analysis as a tool in traffic safety research and practice. // Safety Science. 45, 9(2007), pp. 952-979.

[14] Ewing, R.; Dumbaugh, E. The Built Environment and Traffic Safety A Review of Empirical Evidence. // Journal of Planning Literature. 23, 4(2009), pp. 347-367. https://doi.org/10.1177/0885412209335553

[15] Elvik, R.; Vaa, T.; Erke, A.; Sorensen, M. (Eds.). The handbook of road safety measures. Emerald Group Publishing, 2009. https://doi.org/10.1108/9781848552517

[16] Agencija za bezbednost saobraćaja. (2013). Statistički izveštaj o stanju bezbednosti saobraćaja u Republici Srbiji u 2012. godini http://www.abs.gov.rs/doc/ Statisticki\%20izvestaj\%20o\%20stanju\%20BS\%20u\%20RS \%20za\%202012.pdf (09.02.2015)

[17] Mučenski, V.; Peško, I.; Trivunić, M.; Cirović, G.; Dražić, J. Identification of injury risk in building construction education, experience and type of works. // Tehnički vjesnik-Technical Gazette. 20, 6(2013), pp. 1011-1017.

[18] Gassend, J. L.; Bakovic, M.; Mayer, D.; Strinovic, D.; Skavic, J.; Petrovecki, V. Tractor driving and alcohol-A highly hazardous combination. // Forensic Science International Supplement Series. 1, 1(2009), pp. 76-79. https://doi.org/10.1016/j.fsisup.2009.09.010

[19] Jones, C. B.; Day, L.; Staines, C. Trends in tractor related fatalities among adults working on farms in Victoria, Australia, 1985-2010. // Accident Analysis \& Prevention. 50, (2013), pp. 110-114. https://doi.org/10.1016/j.aap.2012.03.034

[20] Gassend, J. L.; Bakovic, M.; Mayer, D.; Strinovic, D.; Skavic, J.; Petrovecki, V. Tractor driving and alcohol-A highly hazardous combination. // Forensic Science International Supplement Series. 1, 1(2009), pp. 76-79. https://doi.org/10.1016/j.fsisup.2009.09.010

[21] Costello, T. M.; Schulman, M. D.; Luginbuhl, R. C. Understanding the public health impacts of farm vehicle public road crashes in North Carolina. // Journal of agricultural safety and health. 9, 1(2003), pp. 19-32. https://doi.org/10.13031/2013.12347

[22] Janicak, C. A. Occupational fatalities to workers age 65 and older involving tractors in the crops production agriculture industry. // Journal of safety research. 31, 3(2000), pp. 143148. https://doi.org/10.1016/S0022-4375(00)00032-3

[23] Costello, T. M., Schulman, M. D., Mitchell, R. E. Risk factors for a farm vehicle public road crash. // Accident Analysis \& Prevention. 41, 1(2009), pp. 42-47. https://doi.org/10.1016/j.aap.2008.08.029

[24] Ministarstvo unutrašnjih poslova Republike Srbije, Uprava za analitiku http://www.mup.gov.rs/cms_cir/sadrzaj.nsf/ izvestaji.h (25.12.2014)

[25] Erkol, Z.; Buken, B.; Hekimoglu, Y.; Erkol, H.; Ince, H.; Erzengin, O. U. Analysis of tractor-related deaths. // Journal of agromedicine. 18, 2(2013), pp. 87-97. https://doi.org/10.1080/1059924X.2013.767737

[26] Perše, S.; Kovačević, D.; Maković, B. Analyses of Fractures that have Caused Traffic Accidents. // PrometTraffic \& Transportation. 9, 4(2012), pp. 171-175.

[27] Tominc, P.; Šebjan, U. The Impact of Selected Individual and External Factors on the Occurrence of Severe Injuries: Case Study of Slovenia. // Promet-Traffic \& Transportation. 27, 4(2015), pp. 325-334

[28] Weaver, A. A.; Talton, J. W.; Barnard, R. T.; Schoell, S. L.; Swett, K. R.; Stitzel, J. D. Estimated injury risk for specific injuries and body regions in frontal motor vehicle crashes. // Traffic injury prevention. 16, 1(2015), pp. 108-116. https://doi.org/10.1080/15389588.2015.1012664

[29] Bose, D.; Crandall, J. R.; McGwin, G.; Goldman, J.; Foster, J.; Fine, P. R. Computational methodology to predict injury risk for motor vehicle crash victims: A framework for improving advanced automatic crash notification systems. // Transportation research part C: emerging technologies. 19, 6(2011), pp. 1048-1059.

https://doi.org/10.1016/j.trc.2011.06.001

\section{Authors' addresses}

Žarko Bojić, $M S$ c

University of Novi Sad, Faculty of Technical Sciences, Trg Dositeja Obradovića 6, 21000 Novi Sad, Serbia zarko_bojic@yahoo.com

Milan Radošević, assist. prof. dr. sc

University of Novi Sad, Faculty of Technical Sciences, Trg Dositeja Obradovića 6, 21000 Novi Sad, Serbia radosevic@uns.ac.rs

Ilija Ćosi, prof. dr. sc.

University of Novi Sad, Faculty of Technical Sciences, Trg Dositeja Obradovića 6, 21000 Novi Sad, Serbia ilijac@uns.ac.rs

Slobodan Morača, assoc. prof. dr. sc.

(Coresponding author)

University of Novi Sad, Faculty of Technical Sciences, Trg Dositeja Obradovića 6, 21000 Novi Sad, Serbia moraca@uns.ac.rs

\section{Nenad Avramović, PhD}

Univerzitet privredna akademija Novi Sad,

Pravni fakultet za privredu i pravosuđe u Novom Sadu Geri Karolja 1, 21000 Novi Sad, Srbija

avramovic.n@pravni-fakultet.info

\section{Aco Antic, assoc. prof. dr.sc}

University of Novi Sad, Faculty of Technical Sciences, Trg Dositeja Obradovića 6, 21000 Novi Sad, Serbia antica@uns.ac.rs 